\title{
Implementasi Model Pembelajaran Multikultural Untuk Meningkatkan Kompetensi Mahasiswa (Studi Pada Mahasiswa PGMI di IAIN Salatiga)
}

\author{
Rasimin \\ Institut Agama Islam Negeri Salatiga \\ rasimin75@gmail.com
}

\begin{abstract}
Theoretically, multicultural education is a concept of education that provides equal opportunity regardless of gender, class, ethnic, racial, religious, and cultural background of learners. The learning model is carried out by stages: self-exploration studies, exploratorypresentation, peergroup analysis, expert opinion, and reflection. This study aims to improve the competence of mastery of IPS educational materials through multicultural learning model.The research findings show that the implementation of multicultural learning model can improve the competence of mastery of IPS Education materials for PGMI students at IAIN Salatiga. This is evidenced in the average class precycle activity of 60.25; Cycle I of 77.87 and in the second cycle of 82.22. Based on the analysis it is concluded that the implication of multicultural learning model can significantly improve student competence.
\end{abstract}

Keywords: Multicultural Learning and Student Competency

\begin{abstract}
Abstrak
Secara teoritis pendidikan multikultural merupakan konsep pendidikan yang memberikan kesempatan sama tanpa memandang perbedaan gender, kelas sosial, etnik, ras, agama, dan latar kebudayaan peserta didik. Model pembelajaran dilaksanakan dengan tahapan: studi eksplorasi diri, presentasi hasil eksplorasi, peer group analysis, expert opinion, dan refleksi. Penelitian ini bertujuan untuk meningkatkan kompetensi penguasaan materi pendidikan IPS melalui model pembelajaran multikultural. Hasil temuan penelitian menunjukan bahwa implementasi model pembelajaran multikultural dapat meningkatkan kompetensi penguasaan materi Pendidikan IPS bagi mahasiswa PGMI di IAIN Salatiga. Hal ini dibuktikan pada kegiatan prasiklus rata-rata kelas sebesar 60,25; Siklus I sebesar 77,87 dan pada siklus II sebesar 82,22. Berdasarkan analisis disimpulkan bahwa implentasi model pembelajaran multikultural secara signifikan dapat meningkatkan kompetensi mahasiswa.
\end{abstract}

Kata Kunci: Pembelajaran Multikultural dan Kompetensi Mahasiswa

Permalink/DOI:http://dx.doi.org/10.18326/infsl3.v11i1.141-162 


\section{Pendahuluan}

Pembelajaran di perguruan tinggi salah satunya tujuannya adalah untuk meningkatkan kompetensi mahasiswa, baik kompetensi afektif, kognitif maupun psikomotor. Melalui komptensi tersebut, diharapkan mahasiswa mampu meningkatkan daya pikir, bertindak dan berperilaku dalam kehidupan di masyarakat. Kondisi ini sesuai dengan karakteristik ilmu sosial terkait erat dengan gejala-gejala kehidupan sosial sehari-hari. Seorang pendidik termasuk dosen dituntut harus kreatif dalam menemukan sekaligus menerapkan model pembelajaran yang sesuai agar tujuan pembelajaran dapat tercapai.

Berdasarkan hasil observasi yang dilakukan peneliti menunjukkan bahwa pelaksanaan pembelajaran secara umum masih kurang mengoptimalkan aspek kehidupan sosial mahasiswa. Undang-undang Nomor 20 tahun 2003 tentang Sistem Pendidikan Nasional secara jelas menyatakan bahwa pendidikan adalah usaha sadar dan terencana untuk mewujudkan suasana belajar dan proses pembelajaran agar peserta didik secara aktif mengembangkan potensi dirinya untuk memiliki kekuatan spiritual keagamaan, pengendalian diri, kepribadian, kecerdasan, akhlak mulia, serta keterampilan yang diperlukan dirinya, masyarakat, bangsa dan Negara (UUSPN : Pasal 3 ayat 1).

Dengan demikian melalui pendidikan diharapkan apat menghasilkan manusia paripurna yaitu mengembangkan manusia seutuhnya, baik aspek afektif, aspek kognitif, maupun aspek psikomotornya, sehingga peserta didik (mahasiswa) dapat menghadapi berbagai tantangan kehidupan yang dihadapinya. Mendidik adalah menciptakan sistem lingkungan yang memungkinkan terjadinya proses belajar. Sistem lingkungan merupakan komponen-komponen yang saling mempengaruhi, yakni tujuan instruksional, materi, dan peran aktif dalam proses pembelajaran. Idochi Anwar (1996:93) menyatakan bahwa kompleksitas pembelajaran dibutuhkan berbagai strategi yang tepat dalam mengelola pembelajaran di kelas. Adapun komponen yang dimaksud adalah: (1) Tujuan pembelajaran ; (2) latar belakang peserta didik; (3) isi dan struktur materi; (4) biaya mengajar; dan (5) fasilitas. 
Pada prakteknya pendidikan saat ini terlihat adanya gejala penurunan pengembangan potensi yang disebabkan karena proses pembelajaran cenderung berfokus pada pengajar (Aris; 1999:157). Pembelajaran hanya menyajikan pengetahuan yang harus dihafal dan diketahui peserta didik (Laode 1999:4). Bahkan fenomena ini juga terlihat di perguruan tinggi. Pendidikan IPS yang merupakan matakuliah yang diajarkan di Perguruan Tinggi seharusnya lebih menekankan pada pengembangan kompetensi mahasiswa yang bersifat pragmatis-praktis yang dapat mendukung kehidupan seharihari (Naylor,1987:275).

Indonesia merupakan salah satu negara multikultur terbesar di dunia (Aly, 2003:73). Kondisi yang demikian sampai saat ini diibaratkan api dalam sekam, yang suatu saat dapat menimbulkan konflik akibat memanasnya suhu politik, agama, dan sosial budaya. Sehingga diperlukan adanya pandangan yang bersifat inklusif-pluralis, multikultural-humanis, dan dialogis-persuasif. Pendidikan multikultural merupakan kesatuan konsep gerakan reformasi pendidikan yang bersifat kontinum untuk memperkokoh nasionalisme Indonesia yang dapat membawa bangsa ke arah perspektif ke-Indonesia-an secara utuh, dengan ciri-ciri khas masingmasing kelompok masyarakat masih tetap terpelihara (Cardinas, 1975:145).

Dalam konteks ke-Indonesia-an semboyan Bhinneka Tunggal Ika diterapkan secara berat sebelah. Semangat ke-ikaan lebih menonjol daripada semangat ke-bhinneka-an dalam pengelolaan suatu negara. Masyarakat yang sangat plural, seringkali terjatuh pada ketidakstabilan yang rawan dengan sifat disintegrasi, bahkan tak ada jaminan dari politik sentralistik dapat menyatukan potensi yang disintegrasi. Pendidikan nasional yang memiliki misi mencerdaskaan kehidupan bangsa dan merespon perkembangan global, menuntut lembaga pendidikan harus selalu meningkatkan kualitas untuk menghasilkan lulusan yang profesional dan kompetetif. Kondisi tersebut mendorong arah kebijakan pendidikan mengacu pada tiga pilar (Hasbullah, 2006:30-31), yaitu: (1) Perluasan dan pemerataan layanan pendidikan yang bermutu; (2) Peningkatan mutu pembelajaran dan lembaga pendidikan; dan (3) Perbaikan dan kapasistas layanan pendidikan. Ketiga hal tersebut, 
lembaga penddikan diharapkan mampu menjawab tantangan dan kompetisi global dalam merebut pasar kerja baik nasional maupun internasional.

Berdasarkan latar belakang di atas, penelitian ini difokuskan tentang: implementasi model pembelajaran multikultural untuk meningkatkan kompetensi mahasiswa PGMI di IAIN Salatiga. Kajian ini dipilih karena penting dalam mengoptimalkan proses pembelajaran (Peterson, 1997:1), yaitu: (1) Pembelajaran multikultural dimaksudkan untuk dapat membantu dalam menciptakan lingkungan belajar dimana mahasiswa terlibat dalam suatu praktik, aktifitas yang berkelanjutan; (2) Pembelajaran yang terjadi bukan satu arah; dan (3) Pembelajaran akan bersifat fungsional bila didasarkan pada latar belakang sosial budaya mahasiswa secara nyata.

\section{Pendidikan Multikultural}

Pendidikan merupakan upaya yang dilakukan secara sadar dalam rangka mengembangkan potensi yang telah dimiliki oleh manusia kepada kondisi yang lebih baik, yang menyangkut jasmaniah dan rohaniah (Nizar, 2001:VII). Artinya, pendidikan sebagai suatu proses harus dilakukan dengan sadar dan terencana untuk mewujudkan pembelajaran yang efektif agar anak secara aktif dapat mengembangkan potensi dirinya, memiliki kekuatan keagamaan, pengendalian diri, kepribadian, kecerdasan, akhlak mulia serta ketrampilan. Dalam proses belajar mengajar (PBM), pendidik dan peserta didik masing-masing berupaya untuk mengkomunikasikan permasalahan transfer of knowlegde dan transfer of value. Dalam hal ini seorang pendidik secara langsung akan membantu dalam pembentukan karakter dan kepercayaan diri.

Pendidikan nasional berfungsi mengembangkan kemampuan dan membentuk watak serta peradaban bangsa yang bermartabat dalam rangka mencerdaskan kehidupan bangsa yang bertujuan untuk mengembangkan potensi peserta didik agar menjadi manusia yang beriman dan bertaqwa, berahlak mulia, sehat, berilmu, cakap, kreatif, mandiri, dan menjadi warga negara yang demokratis serta bertanggung jawab (UU Sisdiknas, No 20, 2003:12). Untuk 
merealisasikan tujuan tersebut, pendidikan harus menyediakan jalan bagi pertumbuhan yang seimbang dari kepribadian total manusia, yang mencakup aspek spiritual, intelektual, rasional diri, perasaan dan kepekaan sosial, baik secara individu maupun kelompok.

Pendidikan multikultural merupakan konsep pendidikan yang memiliki tiga hal penting, yaitu: (1) semua peserta didik menjadi target group dalam proses pendidikan, tanpa mempertimbangkan latar belakang peserta didik; (2) berorientasi pada perbedaanperbedaan peserta didik; dan (3) integrasi sebagai tujuan utama (Luchternburg, 2003;15). Bahkan pada tahun 1998-an wacana pendidikan multikultural mulai menggema di Indonesia. Wacana tersebut terlihat adanya berbagai diskusi, seminar, dan workshop, penelitian, penerbitan buku, dan jurnal yang bernuansa multikultural. Hal ini dilandasi bahwa Indonesia merupakan negara yang memiliki banyak problematika tentang eksistensi sosial, etnik, dan kelompok keagamaan sangat beragam.

Memperhatikan kondisi tersebut, perlu merekonstruksi kembali kebudayaan nasional Indonesia yang dapat menjadi integrating force yang dapat mengikat seluruh keragaman etnis dan budaya yang ada. Selain itu, pembentukan masyarakat multikultural Indonesia yang demokratis tidak bisa secara taken for granted atau trial and error. Tetapi, harus diupayakan secara sistematis, programatis, integratif, dan berkesinambungan. Langkah yang paling strategis dilakukan adalah melalui pendidikan multikultural di lembaga-lembaga pendidikan, baik formal maupun non-formal (Moeliono, 2002:12; Sugono, 2002:6).

Kondisi masyarakat yang multikultural seperti Indonesia, penerapan pendidikan multikultural merupakan keharusan yang mendesak. Karena, dengan pendidikan multikultural dapat membekali peserta didik untuk bersedia menerima kelompok lain sebagai kesatuan, tanpa mempedulikan perbedaan budaya, etnik, gender, bahasa, maupun agama. Tuntutan pentingnya pendidikan multikultural mendapat respons yang positif dari pihak eksekutif dan legislatif. Hal ini dibuktikan dengan diundangkannya Undangundang Republik Indonesia No. 20 Tahun 2003 tentang Sistem Pendidikan Nasional, yang mengakomodasi nilai-nilai hak asasi 
manusia dan semangat multikultural. Bahkan, nilai-nilai tersebut dijadikan sebagai salah satu prinsip penyelenggaraan Pendidikan Nasional, sebagaimana yang termaktub pada Bab III Pasal 4, yaitu: Pendidikan diselenggarakan secara demokratis dan berkeadilan serta tidak diskriminatif dengan menjunjung tinggi hak asasi manusia, nilai keagamaan, nilai kultural, dan kemajemukan bangsa (UU Sisdiknas, 2003:12).

Bila dipahami secara jelas, ternyata ada hubungan yang signifikan antara pendidikan multikultural, konsep sosial, dan kultur masyarakat. Sebagai contoh Amerika Serikat, Kanada, dan Australia yang memiliki masyarakat multikultural, penduduk aslinya merupakan minoritas dan mayoritas penduduk lainnya merupakan pendatang dari negara lain, sehingga konsep pendidikan multikultural cepat diterima oleh masyarakatnya. Di pihak lain, negara-negara seperti Inggris, Jerman, Prancis, dan Belanda yang merupakan negaranegara kolonial tidak secepat di negara Amerika Serikat, Kanada, dan Australia untuk menerima konsep pendidikan multikultural. Dengan demikian dapat dipahami negara-negara kolonial memiliki kebiasaan diskriminatif terhadap negara-negara jajahannya.

Terdapat beberapa istilah yang berhubungan dengan pendidikan multikultural. Istilah yang sepadan dengan pendidikan multikultural, yaitu: "intcrethnic education, transcultural education, multiethnic education, dan cross-cultural education" Selain itu Driel (dalam Ekstrand, 1997:345) menyebutnya dengan istilah "buman right education dan intercultural education". Sedangkan UNESCO menyebutnya dengan istilah intercultural education, dan inclusive education.

Beberapa istilah di atas, memiliki pengertian yang sama, yaitu suatu konsep pendidikan yang memberikan kesempatan yang setara kepada semua peserta didik. Istilah yang lazim digunakan di berbagai negera seperti Eropa, Australia dan Indonesia adalah intercultural education, multicultural education, dan inclusive education. Dua konsep yang pertama menunjuk kepada pemberian kesempatan yang setara untuk memperoleh pendidikan bagi peserta didik yang memiliki latar belakang budaya dan etnik yang berbeda. Sementara itu, konsep yang terakhir menunjuk kepada pemberian kesempatan 
yang setara untuk memperoleh pendidikan bagi semua peserta didik tanpa melihat keadaan fisik, intelektual, sosial, emosional, bahasa, dan kondisi yang lain.

Secara etimologis, istilah pendidikan multikultural terdiri dari dua kata, yaitu pendidikan dan multikultural. Kata pendidikan, dalam beberapa referensi diartikan sebagai proses pengembangan sikap dan tata laku seseorang atau sekelompok orang dalam usaha mendewasakan manusia melalui upaya pengajaran, pelatihan, proses, perbuatan, dan cara-cara yang mendidik (Dawam, 2003:100). Sementara itu, kata multikultural berasal dari dua kata, yaitu multi dan culture. Secara umum, kata multi berarti banyak, ragam, dan atau aneka. Sedangkan kata culture beberapa makna, yaitu kebudayaan, kesopanan, dan pemeliharaan. Oleh karena itu multikultural diartikan keragaman budaya sebagai bentuk dari keragaman latar belakang seseorang. Secara etimologis pendidikan multikultural didefinisikan pendidikan yang memerhatikan keragaman budaya para peserta didik.

Adapun secara terminologis, pendidikan multikultural didefinisikan menjadi dua kategori, yaitu: (1) dibangun berdasarkan prinsip demokrasi, kesetaraan, dan keadilan; dan (2) dibangun berdasarkan sikap sosial, yaitu: pengakuan, penerimaan, dan penghargaan. Kategori pertama adalah pendidikan multikultural dapat dipahami sebagai konsep pendidikan yang memberikan kesempatan yang sama kepada semua peserta didik tanpa memandang gender dan kelas sosial, etnik, ras, agama, dan karakteristik kultural mereka untuk belajar di dalam kelas (Banks \& Banks, 1989:2).

Disi sisi lain pendidikan multikultural memberikan kesempatan yang setara kepada semua peserta didik yang berbeda latar belakang budaya untuk memperoleh pendidikan, baik di sekolah maupun di perguruan tinggi (Baker, 1999:97-98). Definisi Baker ini berbeda dengan definisi pendidikan multikultural yang dirumuskan oleh Banks. Jika definisi Banks lebih menekankan pada aspek ide, konsep, dan gagasan tentang pendidikan multikultural, maka definisi Baker lebih menekankan pada aspek gerakan dan perjuangan untuk mewujudkan ide dan gagasan pendidikan 
multikultural dalam praktik. Hidalgo (1988:1) mengemukakan bahwa pendidikan multikultural merupakan pembelajaran yang bebas dari rasisme, seksisme, serta bentuk-bentuk dominasi sosial dan intoleran lainnya. Menurut definisi ini, Hidalgo membatasi pendidikan multikultural hanya pada aspek proses pembelajaran di kelas berlangsung secara demokratis, yakni apa pun latar belakang budaya peserta didik akan memperoleh hak dan perlakuan yang sama dari pendidik dan semua peserta didik berhak untuk terlibat aktif tanpa harus merasa superior atau inferior.

Dalam proses pembelajaran, mereka juga memiliki hak yang sama untuk memperoleh perhatian dari para pendidik. Oleh sebab itu, proses pembelajaran dalam pendidikan multikultural tidak akan memberi peluang kepada peserta didik dengan latar belakang budaya tertentu merasa superior atas peserta didik yang lain karena berbeda latar belakang budayanya. Pendidikan multikultural merupakan pendidikan yang membantu para peserta didik untuk mengembangkan kemampuan mengenal, menerima, menghargai, dan merasakan keragaman kultural (Suparlan, 2002, Ramsey, 2008; Yoon, 2012; Mahfud, 2009).

Menurut definisi ini pendidikan multikultural lebih bersifat luas, dalam arti tidak terbatas pada salah satu dari aspek pendidikan, melainkan mencakup semua aspek pendidikan, seperti aspek pendidik, peserta didik, tujuan, materi, kurikulum, metode, dan evaluasi. Dalam hubungan ini, semua aspek pendidikan haruslah diarahkan untuk mengembangkan peserta didik dalam rangka mengenal, menerima, dan menghargai keragaman kultural yang ada di sekolah. Dengan kata lain, kemampuan peserta didik dalam mengenal, menerima, dan menghargai keragaman kultural dapat dikembangkan melalui rumusan tujuan, materi, dan metode pembelajaran.

\section{Karakteristik Pendidikan Multikultural}

Ada tiga karakteristik pendidikan multikultural, yaitu: (1) berprinsip pada demokrasi, kesetaraan, dan keadilan; (2) berorientasi kepada kemanusiaan, kebersamaan, dan kedamaian; dan (3) mengembang- 
kan sikap mengakui, menerima, dan menghargai keragaman budaya. Beberapa karakteristik tersebut dapat dipahami secara jelas sebagai berikut:

Pertama. Berprinsip pada Demokrasi, Kesetaraan, dan Keadilan. Prinsip demokrasi, kesetaraan, dan keadilan merupakan prinsip yang mendasari pendidikan multikultural, baik pada level ide, proses, maupun gerakan. Ketiga priiisip ini menggaris bawahi bahwa semua anak memiliki hak yang sama untuk memperoleh pendidikan. Karakteristik pendidikan multikultural yang berprinsip kepada demokrasi, kesetaraan, dan keadilan ini agaknya sejalan dengan program UNESCO tentang education for all vaitu program pendidikan yang memberikan peluang yang sama kepada semua anak untuk memperoleh pendidikan. Sebenarnya tidak hanya terbatas pada pemberian kesempatan yang sama kepada semua anak untuk memperoleh pendidikan, melainkan juga berarti bahwa semua peserta didik harus memperoleh perlakuan yang sama untuk memperoleh pelajaran di dalam kelas (Rasyada, 2004:18). Perlakuan yang sama ini, mereka akan memperoleh peluang untuk mencapai kompetensi keilmuan dan keterampilan yang sesuai dengan minat mereka. Dalam kaitan ini, pendidikan multikultural akan menjamin semua peserta didik memperoleh perhatian yang sama, tanpa membedakan latar belakang warna kulit, etnik, agama, bahasa, dan budaya peserta didik.

Kedua. Berorientasi kepada Kemanusiaan, Kebersamaan, dan Kedamaian. Untuk mengembangkan prinsip demokrasi, kesetaraan, dan keadilan dalam kehidupan bermasyarakat, terutama di masyarakat yang heterogen, diperlukan orientasi hidup yang universal. Di antara orientasi hidup yang universal adalah kemanusiaan, kebersamaan, dan kedamaian. Orientasi hidup yang universal ini merupakan titik orientasi bagi pendidikan multikultural. Dengan demikian, pendidikan multikultural menentang adanya praktik-praktik hidup yang menodai nilai-nilai kemanusiaan, kebersamaan, dan kedamaian seperti kekerasan, permusuhan, konflik, dan individualistik. Orientasi pertama bagi pendidikan multikulturaladalah orientasi kemanusiaan. Kemanusiaan (bumanity) yang dijadikan titik orientasi oleh pendidikan multikultural dapat dipahami sebagai nilai yang menempatkan peningkatan 
pengembangan manusia, keberadaannya, dan martabatnya sebagai pemikiran dan tindakan manusia yang tertinggi dalam kebudayaan. Karena multicultural merupakan alat untuk meningkatkan derajat manusia dan kemanusiaannya, maka konsep kebudayaan harus dilihat fungsinya bagi keidupan manusia (Suparlan, 2002; Ramsey, 2008; Yoon, 2012; Mahfud, 2009). Sebagai manusia bermartabat terdapat tiga prinsip dalam kemanusiaan, vaitu: (1) otonomi, rasional, dan penghargaan untuk semua orang; (2) kesetaraan dan kebersamaan; dan (3) komitmen untuk membantu semua orang dalam pengembangan potensinva. Jika prinsip pertama bersifat tilosofis, sementara prinsip kedua bersifat sosio-politis, sedangkan prinsip ketiga bersifat pedagogis (Cardinas, 1975; Abdullah, 2003).

Ketiga. Mengembangkan Sikap Mengakui, Menerima, dan Menghargai Keragaman. Untuk mengembangkan orientasi hidup kemanusiaan, kebersamaan, dan kedamaian di masyarakat yang majemuk diperlukan sikap sosial yang positif. Sikap sosial positif ini, antara lain mengambil bentuk kesediaan untuk mengakui, menerima, dan menghargai keragaman. Pendidikan multikultural memiliki perhatian kuat terhadap pengembangan sikap-sikap sosial yang positif tersebut. Dengan demikian, pendidikan multikultural menolak sikap-sikap sosial yang cenderung rasial, stereotip, dan berprasangka buruk kepada orang atau kelompok lain yang berbeda suku, ras, bahasa, budaya, dan agama. Menurut Donna M. Gollnick (1983:23), sikap menerima, mengakui, dan menghargai keragaman ini diperlukan dalam kehidupan sosial di masyarakat yang majemuk. Karena dalam pandangannva, penerimaan, pengakuan, dan penghargaan terhadap keragaman laksana mosaik dalam suatu masyarakat. Di dalam mosaik tercakup semua kebudayaan dari masyarakat-masvarakat yang lebih kecil (microculture) yang membentuk terwujudnya masyarakat yang lebih besar (macroculturer). Sementara itu, bagi Lawrence A. Blum (2001:19), penerimaan, pengakuan, dan penghargaan terhadap keragaman merupakan sikap sosial yang diperlukan dalam membangun hubungan sosial yang harmonis di dalam masyarakat yang majemuk.

Dengan memerhatikan definisi-definisi di atas, dapat diperoleh tiga karakteristik pendidikan multikultural, yaitu: (1) berprinsip pada demokrasi, kesetaraan, dan keadilan; (2) ber- 
orientasi kepada kemanusiaan, kebersamaan, dan kedamaian; dan (3) mengembangkan sikap mengakui, menerima, dan menghargai keragaman budaya.

\section{Tahapan Pembelajaran Multikultural}

Pembelajaran merupakan instrumen yang sangat strategis dalam menentukan keberhasilan proses belajar mengajar. Keberadaannya secara langsung dapat memberikan dinamika tersendiri bagi peserta didik untuk menyerap isi materi dan penjelasan bahan ajar yang disampaikan pendidik. Proses pembelajaran akan berjalan efektif apabila didukung dengan tersedianya fasilitas pembelajaran yang memadai. Penyediaan fasilitas pembelajaran dengan pengelolaan proses yang dinamis, kondusif, dialogis interaktif, dan motivatif sangat diperlukan bagi eksplorasi dan pengembangan potensi peserta didik secara optimal. Proses pembelajaran yang dinamis, kondusif, dialogis interaktif dan motivatif ini sulit diwujudkan dengan performance guru yang hanya mengandalkan kemampuan berbicara tanpa melihat aspek lain yang lebih strategis dalam mempengaruhi peserta didik.

Model pembelajaran masing-masing mengedepankan keunggulan dalam mengupayakan pencapaian sasaran yang diyakini oleh setiap pengembangannya, namun untuk penerapan praktis di tempat yang sangat mungkin berbeda, harus disesuaikan kemampuan dengan berbagai aspek dengan segala keterbatasan kondisi yang ada karena tentu tidak sama. Sekurang-kurangnya dimana, oleh, atau dengan dan terutama untuk siapa proses pembelajaran dilakukan. Khusus berkaitan dengan kebutuhan pembelajaran pada mahasiswa pertumbuhan, dari sejumlah model tentunya dapat dirujuk model pembelajaran yang menjadi rujukan dengan sebutan model Cognitive Emotion and Social Development. Dasar pandangannya adalah mahasiswa merupakan produk berbagai pengaruh, mulai dari keluarganya, kesehatan, kondisi sosial ekonomi dan sekolah". Bahwa masing-masing pendekatan pada pandangan teoritis berkenaan dengan stressingnya, dalam praktisnya dapat terjadi saling berkait antara satu pendekatan dengan pendekatan lain secara bersamaan. Untuk itu, memenuhi 
keperluan teknis operasional dalam mengembangkan pembelajaran Pengetahuan Sosial berbasis pendekatan nilai khususnya, berikut dipetikan langkah teknis sejumlah model pilihan yang dipandang mewakili tuntutan karakteristik materil, peserta didik dan setting sosial yang menjadi lingkungan kultur. Seorang dosen dalam melaksanakan tugasnya tidak dapat meninggalkan apa yang disebut dengan model pembelajaran dan penerapannya di kelas. Untuk meningkatkan pemahaman tentang berbagai model pembelajaran, perlu memperhatikan beberapa model pembelajaran. Adapun tahapan tindakan yang dilakukan dalam model pembelajaran multikultural adalah:

Pertama. Studi eksplorasi diri. Lingkungan sosio-budaya peserta didik yang potensial dengan substansi multikultural, menugaskan kepada peserta didik untuk melakukan eksplorasi lokal, yang meliputi diri sendiri dan lingkungan sosial-budaya. Kedua. Presentasi hasil eksplorasi. Peserta didik mempresentasikan hasil eksplorasi (bisa individual atau kelompok) terhadap masalah sosialbudaya (lokal) yang menarik bagi dirinya dihadapan teman atau kelompok lain. Ketiga Peer group analysis. Teman lain atau peserta didik yang telah dibagi menjadi beberapa kelompok, dimohon untuk mengalisis dan memberi komentar terhadap presentasi hasil eksplorasi masalah terpilih. Secara bergiliran masing-masing peserta didik atau kelompok memprensentasikan hasil analisisnya. Keempat. Expert opinion. Pendidik memberikan komentar mengenai hasil eksplorasi yang dipresentasikan dan beberapa komentar teman. Kelima. Refleksi. Rekomendasi dan membangun komitmen pendidik bersama peserta didik melakukan refleksi tampilan peserta didik terhadap keunggulan nilai-nilai sosio- budaya lokal yang diperkirakan memiliki potensi dan prospek dalam membangun komitmen nilai yang dapat digunakan sebagai perekat persatuan dan kesatuan kehidupan lokal maupun kehidupan nasional.

\section{Kompetensi Mahasiswa}

Mahasiswa merupakan anggota masyarakat yang berusaha mengembangkan potensi diri melalui proses pembelajaran yang tersedia pada jalur, jenjang dan jenis tertentu (Sisdiknas, 2003:9). 
Setiap anak mempunyai potensi kreatifitas yang berbeda dan harus dikembangkan, yaitu melalui proses pembelajaran yang dibantu oleh pendidik. Dalam perkembangannya, anak akan dipengaruhi oleh keluarga, sekolah dan masyarakat. Djamarah mendefinisikan bahwa mahasiswa merupakan setiap orang yang menerima pengaruh dari seseorang atau sekelompok orang yang menjalankan kegiatan pendidikan (Djamarah,2000:51). Mahasiswa sebagai kunci terjadinya interaksi edukatif, sebagai makhlukmanusia yang berpotensi, maka di dalam dirinya terdapat suatu daya yang dapat tumbuh dan berkembang di sepanjang usianya. Menurut Hutapea (2008:2-3) kompetensi sebagai gambaran tentang apa yang seharusnya diketahui atau dilakukan seseorang agar dapat melaksanakan pekerjaannya dengan baik. Pengertian kompetensi jenis ini dikenal dengan nama kompetensi teknis atau fungsional (technical/functional competencies). Kompetensi yang menggambarkan bagaimana seseorang diharapkan berperilaku agar dapat melaksanakan pekerjaannya dengan baik. Pengertian kompetensi jenis ini dikenal dengan nama kompetensi perilaku (behavioral competencies) atau juga disebut dengan kompetensi lunak (soft competency).

Karakteristik atau kompetensi yang melekat pada individu terlihat pada cara berperilaku ditempat kerja seseorang. Kompetensi dapat bersumber dari tiga jenis sumber kompetensi yang berbeda, yaitu: (1) Konsep Diri. Kensep diri seseorang mencakup gambaran atas diri sendiri, sikap dan nilai-nilai yang diyakininya. Misalnya, seseorang yang memiliki rasa percaya diri yang tinggi menggambarkan dirinya sendiri sebagai orang yang dapat mencapai sesuatu yang diharapkan, yang menurutnya, baik dalam berbagai situasi, baik situasi sulit maupun mudah; (2) Pengetahuan. Pengetahuan mencerminkan informasi yang dimiliki seseorang pada area disiplin yang tertentu yang spesifik. Nilai akademis atau indeks prestasi akademis seringkali kurang bermanfaat untuk memprediksi performansi di tempat kerja, karena sulitnya mengukur kebutuhan pengetahuan dan keahlian yang secara nyata digunakan dalam pekerjaan; dan (3) Keterampilan. Adalah kemampuan untuk melakukan aktivitas fisik dan mental. Kompetensi keterampilan mental atau kognitif meliputi pemikiran analitis serta pemikiran 
konseptual (pengenalan pola data yang kompleks). Kompetensi motif, karakter, dan konsep diri memprediksi prilaku keahlian, yang kemudian memprediksikan hasil kinerja. Perlu diperhatikan dalam kompetensi, yaitu kompetensi yang mencakup unsure pengetahuan, sika, ketrampilan dan pengalaman.

\section{Metode Penelitian}

Model penelitian yang digunakan dalam penelitian ini adalah model penelitian tindakan kelas (PTK) dengan implementasi model pembelajaran multicultural pada pembelajaran pendidikan IPS pada mahasiswa PGMI IAIN Salatiha. Penelitian ini dilakukan berdasarkan pada permasalahan yang muncul dalam pembelajaran pendidikan IPS bagi mahasiswa PGMI IAIN Salatiga. Berdasarkan pengamatan pra-siklus (tindakan) dan diskusi serta saran dari berbagai pihak. Maka langkah yang paling tepat untuk meningkatkan kompetensi mahasiswa PGMI IAIN Salatiga adalah dengan melakukan penelitian tindakan kelas dengan model pembelajaran multikultural dengan prosedur pelaksanaan penelitian tindakan kelas sebagai berikut: (1) Perencanaan; (2) Pelaksanaan tindakan, (3) Observasi; dan (4) Refleksi dalam setiap siklus (Sukmadinata, 2008:145).

Teknik pengumpulan data yang digunakan dalam penelitian ini adalah: (1) Observasi/Pengamatan. Observasi dimaksudkan untuk mengukur perubahan kompetensi baik afektif, kognitif dan psikomotor mahasiswa sebagai indikasi dari keberhasilan dalam proses pembelajaran; (2) Dokumentasi. Dalam mencari sumber informasi melalui studi dokumentasi peneliti mengumpulkan dan menyelidiki benda-benda tertulis seperti buku, dokumen, peraturan-peraturan, notulen rapat, catatan harian dan sebagainya notulen rapat, catatan harian dan sebagainya; (3) Hasil Tes/Evaluasi. Tes hasil belajar berarti memeriksa hasil belajar yang dicapai oleh mahasiswa, hasil belajar tersebut berupa kemampuan mahasiswa. Tes juga menyangkut kemampuan mahasiswa sebelum pengajaran dimulai atau pretes yang berfungsi mengetahui tingkah laku yang dimiliki mahasiswa. 


\section{Analisis}

Berdasarkan studi pendahuluan penguasaan materi pendidikan ilmu pengetahuan sosial mahasiswa PGMI IAIN Salatiga sebelum diterapkan model pembelajarn multikultural menunjukan bahwa kompetensi mahasiswa baik afektif, kognitif maupun psikomotor tergolong rendah. Kondisi demikian dapat dilihat dalam tabel berikut:

Tabel: 1

Rata-Rata Hasil Pretes Pra-Siklus Sebelum Penerapan Model Pembelajaran Multikultural

\begin{tabular}{cccccc}
\hline No & $\begin{array}{c}\text { Rentang } \\
\text { Nilai }\end{array}$ & Kategori & Frekuensi & Prosentase & $\begin{array}{c}\text { Rata-rata } \\
\text { Kelas }\end{array}$ \\
\hline $40-54$ & Kurang & 7 & $20 \%$ & \\
$55-69$ & Cukup & 20 & $55 \%$ & 55,38 \\
$70-84$ & Baik & 6 & $17,5 \%$ & \\
$85-100$ & Sangat Baik & 2 & $7,5 \%$ & \\
& & 35 & $100 \%$ & \\
\hline
\end{tabular}

Berdasarkan tabel di atas menunjukkan bahwa kompetensi mahasiswa pada matakuliah Pendidikan IPS sebelum diterapkan model pembelajaran multikultural mencapai rata-rata kelas 55,38 dalam kategori cukup dengan rincian sebagai berikut; dari nilai 40-54 sebanyak 7 mahasiswa atau sekitar 20\%, mahasiswa yang memperoleh nilai cukup dengan rentang nilai 55-69 sebanyak 20 mahasiswa atau 55\%. Mahasiswa yang mendapat nilai baik dengan rentang nilai 70-84 sebanyak 6 mahasiswa atau 17,5\% sedangkan yang mendapat nilai sangat baik hanya 2 mahasiswa atau 7,5\%. Nilai ratarata kelas 55,38 yang artinya masih di bawah nilai standar kelulusan yakni $65(2,0)$ dengan kondisi awal tersebut maka perlu diadakan tindakan. Data ini menunjukan bahwa metode perkulaahn dengan menggunakan metode konvensional relatif kurang begitu diminati mahasiswa dan kurang bisa memberikan efek signifikan terhadap kompetensi mahasiswa. Oleh sebab itu perlu dilakukan modifikasi metode dalam pembelajaran. Sedangkan setelah diterapkan model pembelajaran multikultural pada Siklus I secara rinci hasil dapat dilihat dalam tabel berikut: 
Tabel: 2

Rata-Rata Hasil Test Siklus I Penerapan Model Pembelajaran Multikultural

\begin{tabular}{llllll}
\hline No & $\begin{array}{l}\text { Rentang } \\
\text { Nilai }\end{array}$ & Kategori & Frekuensi & Prosentase & Rata-rata Kelas \\
\hline 1 & $40-54$ & Kurang & 13 & 47,5 & \\
2 & $55-69$ & Cukup & 15 & 62,5 & 60,25 \\
3 & $70-84$ & Baik & 5 & 77,5 & \\
4 & $85-100$ & Sangat & 2 & 92,5 & \\
& & Baik & 35 & 2410 & \\
\hline
\end{tabular}

Berdasarkan tabel di atas menunjukkan bahwa hasil belajar matakuliah Pendidikan IPS bagai mahasiswa PGMI IAIN Salatiga setelah menggunakan metode pembelajaran multikultural mencapai rata-rata kelas 60,25 dalam kategori cukup dengan rincian sebagai berikut; dari nilai 85-100, 2 mahasiswa atau sekitar 5\%, mahasiswa yang memperoleh nilai baik 5 mahasiswa atau 12,5 5 dengan rentang nilai 70-84, yang mendapat nilai cukup 15 mahasiswa dengan rentang nilai 55-69, mahasiswa yang mendapat nilai kurang 13 mahasiswa atau 37,5 \% dengan rentang nilai 40-54. Model pembelajaran multiklutural adalah sebuah model pembelajaran yang memberikan kesempatan sepenuhnya kepada mahasiswa untuk mengkaji dan mengeksplorasi lingkungan sosial mahasiswa yang potensial untuk dijadikan materi perkuliahan. Dalam arti mahasiswa mencari memanfaatkan sumber belajar dari lingkungan yang telah disesuaikan dengan latar belakang sosial budaya mahasiswa. Berdasarkan tabel tersebut dapat dijelaskan bahwa implementasi model pembelajaran multikultural dalam pembelajaran Pendidikan IPS berakibat terhadap meningkatnya kompetensi mahasiswa, baik kompetensi kognitif. Hal ini dapat dilihat dari peningkatan kondisi awal mahasiswa sebelum dilakukan model pembelajaran multiklutural memiliki rata-rata kelas 55,38. Setelah diterapkan model pembelajaran multikultural rata-rata kelas naik signifikan menjadi 60,25.

Pada siklus I kegiatan pembelajaran ini sudah baik, ada beberapa aspek yang belum mencapai 100\% antara lain persiapan 
dosen memulai kegaiatan pembelajaran 50\%, kemampuan dosen mengelola kelas 25\%, menyajikan pertanyaan atau permasalahan 50\%, membimbing membuat kesimpulan 50\%. Sehingga diperlukan adanya tindakan lebih lanjut pada siklus II agar lebih baik. Kegiatan mahasiswa dalam pembelajaran ini dalam kategori cukup yaitu $67,86 \%$ dapat disimpulkan bahwa prosentase tiap variabel belum bisa maksimal. Sedangkan pada kegiatan siklus II mengalami perubahan yang sangat baik, dapat dilihat pada tabel di bawah ini:

\section{Tabel:3}

\section{Rata-Rata Hasil Test Siklus II dengan Penerapan Model Pembelajaran Mulltikultural}

\begin{tabular}{|c|c|c|c|c|c|}
\hline No & $\begin{array}{l}\text { Rentang } \\
\text { Nilai }\end{array}$ & Kategori & Frekuensi & Prosentase & $\begin{array}{l}\text { Rata-rata } \\
\text { Kelas }\end{array}$ \\
\hline & $40-54$ & Kurang & 0 & $0 \%$ & \multirow{5}{*}{77,87} \\
\hline & $55-69$ & Cukup & 8 & $25 \%$ & \\
\hline & $70-84$ & Baik & 17 & $47,5 \%$ & \\
\hline & $85-100$ & Sangat baik & 10 & $27,5 \%$ & \\
\hline & & & 35 & & \\
\hline
\end{tabular}

Berdasarkan tabel di atas dapat diketahui bahwa hasil tes pada siklus II mengalami perubahan yang baik yaitu dengan ratarata kelas 77,87 lebih baik dibanding dari siklus I nilai mahasiswa naik dengan 10 atau 27,5\% mahasiswa mendapat nilai sangat baik dengan rentang nilai 85-100, mahasiswa mendapat nilai baik dengan rentang nilai 70-84 sejumlah 17 mahasiswa atau sekitar 47,5\%. Mahasiswa mendapat nilai cukup sejumlah 8 mahasiswa atau 25\% dengan rentang nilai 55-69, dan tak satu pun yang mendapat nilai kurang dengan rentang nilai 40-54.

Pada siklus II ini berdasarkan pengamatan kegiatan peneliti melakukan pembelajaran dengan menggunakan model multikultural 100\% dalam kategori sangat baik. Pengamatan terhadap mahasiswa juga mengalami kemajuan dari pada siklus I. Pada siklus II mencapai 96,43\% dalam kategori sangat baik. Pelaksanaan siklus II mampu memperbaiki siklus I. Hal ini ditunjukkan mahasiswa lebih aktif dalam pembelajaran, mereka melakukan studi eksplorasi, dan 
presentasi hasil eksplorasi untuk melakukan peer group analysis atas permasalahan baik secara individu maupun maupun kelompok serta mampu menyelesaikan berbagai permasalahan yang terjadi. Kegiatan peneliti pada siklus II juga menunjukkan bahwa peneliti lebih aktif, mampu memotivasi mahasiswa dan mampu menjelaskan masalah dengan baik serta melaksanakan peranannya yang utama sebagai fasilitator dan pendamping mahasiswa dalam melakukan peer group analysis untuk memecahkan suatu masalah. Berdasarkan hasil pada siklus II, maka tindakan dalam siklus dihentikan, karena hasil yang diharapkan sudah maksimal dan mencapai rata-rata 85\%.

Berdasakan hasil Siklus I dan II dengan model pembelajaran mulitikultural yang memaksimalkan seluruh kemampuan mahasiswa untuk mencari dan menyelidiki secara sistematis, kritis, analitis berdasarkan kondisi sosialbudaya melalui studi eksplorasi, mahasiswa dapat merumuskan sendiri penemuannya dan mengembangkan sikap percaya diri, sehingga kompetensi efektif, kognitif maupun psikomotor mahasiswa dapat dioptimalkan. Berikut gambaran hasil penelitian dengan menerapkan model pembelajaran multikultural dapat meningkatkan kompetensi mahasiswa.

Tabel: 4

\section{Peningkatan Hasil Belajar Siklus I dan II dengan penerapan model pembelajaran multikultural}

\begin{tabular}{llll}
\hline No & Siklus & Rata-rata Hasil Belajar & Peningkatan (\%) \\
\hline 1 & Siklus I & 60,25 & \\
2 & Siklus II & 77,87 & $17,62 \%$ \\
\hline
\end{tabular}

Berdasarkan tabel di atas tampak bahwa kompetensi mahasiswa dari siklus I sampai dengan siklus II mengalami peningkatan. Pada siklus I kompetensi rata-rata yang diperoleh adalah 60,25 meningkat menjadi 77,87 pada siklus II sehingga dapat disimpulkan bahwa implementasi model pembelajaran multikultural dapat meningkatkan kompetensi penguasaan materi pendidikan IPS pada mahasiswa PGMI IAIN Salatiga. Selanjutnya data hasil siklus 
I dan siklus II dianalisis untuk memahami keadaan kelas setelah adanya penelitian tindakan kelas.

Tabel.10

Frekuensi Perolehan Nilai Pada Siklus I dan II dengan penerapan model pembelajaran multikultural

\begin{tabular}{lll}
\hline Rentang Nilai & Siklus I & Siklus II \\
\hline $40-54$ & 13 & 0 \\
$55-69$ & 15 & 5 \\
$70-84$ & 5 & 19 \\
$85-100$ & 2 & 11 \\
& 35 & 35 \\
\hline
\end{tabular}

Tabel.5

Hasil Penghitungan Fh Untuk Tiap-Tiap Siklus Setelah Penerapan Model Pembelajaran Multicultural

\begin{tabular}{ccc}
\hline Rentang Nilai & Siklus I & Siklus II \\
\hline $40-54$ & 7,5 & 7,5 \\
$55-69$ & 14 & 14 \\
$70-84$ & 12 & 12 \\
$85-100$ & 6,5 & 6,5 \\
\hline
\end{tabular}

Tabel.6

Harga $\mathrm{X}^{2}$ Dari Siklus I Dan Siklus II Setelah Penerapan Model Pembelajaran Multikultural

\begin{tabular}{llllll}
\hline Kategori & Fo & Fh & fo-fh & ${\text { (fo-fh })^{2}}^{\frac{(f o-f h)^{2}}{\text { fh }}}$ \\
\hline Siklus I & & & & & \\
$40-54$ & 13 & 7,5 & 7,5 & 56,25 & 7,50 \\
$55-69$ & 15 & 14 & 4 & 16 & 1,14 \\
$70-84$ & 5 & 12 & -7 & 49 & 4,80 \\
$85-100$ & 2 & 6,5 & $-4,5$ & 20,25 & 3,11
\end{tabular}


Siklus II

$\begin{array}{llllll}40-54 & 0 & 7,5 & -7,5 & 56,25 & 7,50 \\ 55-69 & 5 & 14 & -4 & 16 & 1,14 \\ 70-84 & 19 & 12 & 7 & 49 & 4,08 \\ 885-100 & 11 & 6,5 & 4,5 & 20,25 & 3,11 \\ & & & & & 32,38\end{array}$

Dari pengujian data tersebut di peroleh $\mathrm{X}^{2}=32,38$. Kemudian untuk menginterprestasikan terlebih dahulu ditentukan derajat kebebasan dengan $\mathrm{dk}=(\mathrm{k}-1)(\mathrm{b}-1)=(2-1)(4-1)=3$. Pada taraf signifikannsi $5 \% \mathrm{X}^{2} 0,05=7,815$ sedangkan pada taraf signifikansi $1 \%, X^{2} 0,01=11,341$. Sedangkan untuk $X^{2} 0=32,38$. Dengan demikian $\mathrm{X}^{2} \mathrm{O}>\mathrm{X}^{2}$ berarti signifikan, dari dua taraf signifikansi ini dapat ditafsirkan bahwa: (1) Perbedaan antara fo dan fh adalah meyakinkan atau dapat dikatakkan bahwa ada perbedaan antara fo dan fh, maka hipotesis diterima, dan (2) Pengaruh antara penerapan model pembelajaran multikultural dengan kompetensis mahasiswa adalah meyakinkan.

Model pembelajaran multicultural sangat efektif digunakan dalam pembelajaran Pendidikan IPS dapat mengaktifkan mahasiswa dalam pembelajaran. Penerapan model pembelajaran multikultural sebagai model pembelajaran multikultural mengaktifkan mahasiswa dalam proses pembelajaran Pendidikan IPS. Pembelajaran dengan menggunakan model pembelajaran multikultural dapat meningkatkan kompetensi afektif, kognitif dan psikomotor mahasiswa. Hal ini terlihat dari hasil tes mahasiswa siklus I rata-rata kelas sebesar 60,25. Pada siklus II meningkat menjadi 77,87 dengan ketuntasan klasikal 55,55 \% sedangkan pada siklus II rata-rata kelas 82,22 dengan ketuntasan klasikal sebesar 83,33\%.

\section{Kesimpulan}

Berdasarkan hasil penelitian dan pembahasan dapat disimpulkan sebagai berikut: (1) Kemampuan kompetensi mahasiswa baik afektif, kognitif, maupun psikomotor dalam penguasaan mata kuliah Pendidikan IPS mahasiswa PGMI IAIN Salatiga sebelum dilakukan tindakan belum optimal, hal ini bisa diketahui dari rata- 
rata kelas yang hanya mencapai 55,68. Nilai tersebut masih dibawah kriteria kelulusan minimal yaitu 65; (2) sedangkan setelah di terapkan model pembelajaran multikultural kompetensi mahasiswa dalam penguasaan materi pendidikan IPS mengalami peningkatan cukup signifikan sebesar 17,62\% dari siklus I dan siklus II; dan (3) implementasi model multikultural dapat meningkatkan kompetensi penguasaan materi pendidikan IPS pada mahasiswa PGMI IAIN Salatiga.

\section{Daftar Pustaka}

Abdullah, M. Amin. 2005. Pendidikan Agama Era Multikultural, Multi Religius. Jakarta: PSAP Muhammadiyah.

Ali, Muhamad. 2003. Teologi Pluralis-Multikultural: Menghargai Kemajemukan Menjalin Kebersamaan. Jakarta. Penerbit Buku Kompas.

Aly, Abdullah. 2004. Pendidikan Islam Berwawasan Multikultural. Yogyakarta: Bina Insani Press.

Bank, A. James. 1981. Multiethnic Education Theory and Practice. Allyn an Bacon. Inc: Bostom

Departemen Pendidikan dan Kebudayaan. 1996. Kamus Lengkap Bahasa Indonesia. Jakarta: Balai Pustaka.

Ekstrand, L.H. 1997. Multicultural Education dalam International Encyclopedia of the Sociology of Education. New York: Pergamon.

Elashmawi, farid \& Harris, Philip R. 1994. Multicultural Management:

New Skill for Global Success. Malaysia: S. Abdul Majeed \& Co.

Farris,P.J. \& Cooper,S.M. 1994. Elementary Social Studies: a Whole language Approach. Iowa: Brown \& Benchmark Publishers. Garcia, Ricardo L. 1982. Teaching in a Pluralistic society; Concepts, Models, Strategies. New York: Harper \& Row Publiser.

Gollnick, Donna M. 1983. Multicultural Education in a Pluralistik Society. London: The CV Mosby Company.

Hidalgo, Francisco. 1988. Multicultural Education landscape for Reform in the Twently-first Century. New York: Pergamon 
Hutapea P, Thoha N. 2008. Kompetensi, Teori, Desain, Kasus, dan Penerapannya untuk Organisasi yang Dinamis. Jakarta: Gramedia Pustaka Utama.

Kemmis, Stephen \& Mc Taggart, Robbin. 1988. The Action Research Planner. Victoria:Deakin University.

Laaser, U. 2010. Public Health Competencies and Performance Standarts. Woeld Federation of Public Health Associations. Presented in 11 th National Congress of the Indonesia Public Health Association. Bandung August 3-5 2010.

MacVaogh. Jason. 1988. Problem Based Learning: the ability to conduct independent inquiry into real-life issus. University of Gloucestershire Business School and the Centre for Active Learning.

Mahfud, Choirul. 2010. Pendidikan multikultural. Yogyakarta: Pustaka Pelajar.

Marcangelo, Caroline. 2009. Problem Based Learning Evaluation Toolkit. Crumbia: The Higher Education Akademy.

Munthe, Bermawy. 2009. Desain Pembelajaran. Yogyakarya: Pustaka Insan Madani.

Ramsey, P.G. 2008. History and Trend of Multicultural Education. New York: NY Cotinuum.

Sauqi, A dan Naim, N. 2008. Pendidikan Multikultural; Konsep dan Apliksinya. Yogyakarta: Ar-Ruzz Media.

Smith, Mark K. 2002. Curriculum Theory and Practice. London; Routledge.

Starr, Linda. 2004. Speaking of Classroom Management: An Interview. New York: Row Publiser.

Sugiyono. 2009. Metode Penelitian Pendidikan: Pendekatan Kuantitatif-Kualitatif dan R \& D. Bandung: Alfabeta.

Taylor, D.. 2006. Guide to Problem Based Learning. School of Medical Education University of Liverpool.

Trianto. 2007. Model-Model Pembelajaran Inovatif Berorientasi Konstruksivistik: Konsep, Landasan Teoritis Praktis, dan Implemtasinya. Jakarta: Prestasi Pustaka.

Usman, Husaini. 2008. Manajemen: Teori, Praktik dan Riset Pendidikan, Edisi Kedua. Jakarta: Bumi Aksara. 